\title{
Individual and Perceptual Characteristics Influences On E-learning Outcomes
}

\author{
Rabeb Mbarek \\ University of Sousse, Department of Management and Organization, Nabel, Tunisia
}

\begin{abstract}
This paper aims to study the influence of individual and perceptual characteristics on elearning outcomes. A conceptual model, based on the social cognitive theory, technology acceptance theory and training evaluation model, is developed and tested on 410 trainees, in Tunisian context. Data analysis conducted by structural equations shows the importance of motivation to learn, perceptual usefulness and ease of use as factors that influence e-learning outcomes.
\end{abstract}

Keywords: e-learning, structural equations, outcomes

\section{Introduction}

Today, the obstruction for the knowledge and the training is attached to the problematic of the innovation: "learn because it's necessary to enhance competitiveness". Organizations have, recently, recognized that a professional training program is an important means of success procuring competitive advantage in today's economy. In fact, employees are the interior customers of the organization that it's necessary to be careful to satisfy the renewing of their knowledge, their knowledge to make and their knowledge to be. Such investment in the employees' skills development cannot be provided that by "the reengineering of the training". Information technology has increased dramatically in the last years and has contributed to the growth in technology delivered instruction as an important education method.
In recent years, the academic research and reviews have increased. More specifically, the scientific conferences have published elearning studies in the ambition to understand the impact of learning across different types of delivery on the employees' performance on the one hand, and the competitiveness of organization on the other hand. Moreover, the academic research on e-learning effectiveness is becoming one of the current themes (Lim \& al, 2007). The present research seeks indentification of the influence of motivation on learning, computer self efficacy, ease of use and perceived usefulness on e-learning outcomes. Moreover, this research considers the possible influences between individual and perceptual characteristics.

To address the question of e-learning effectiveness, this study examines the variables that contribute to enhance learning and learning transfer. Specifically, the present 
research considers four research questions regarding e- learning effectiveness. (1)To what degree do individual and perceptual characteristics influences e-learning outcomes? (2) To what degree learning influences learning transfer? (3) To what degree the computer self efficacy influences motivation to learn? (4) To what degree ease of use influences perceived usefulness?

\section{Conceptual model and hypotheses}

We propose to study the influence of two antecedents of e-learning effectiveness. These antecedents are "individual and perceptual ones. Specifically, we identify motivation to learn and computer self efficacy as two individual characteristics, and ease of use and perceived usefulness as two perceptual characteristics.

These factors are based on social cognitive theory, and technology acceptance theory. The theoretical model is shown in figure 1:

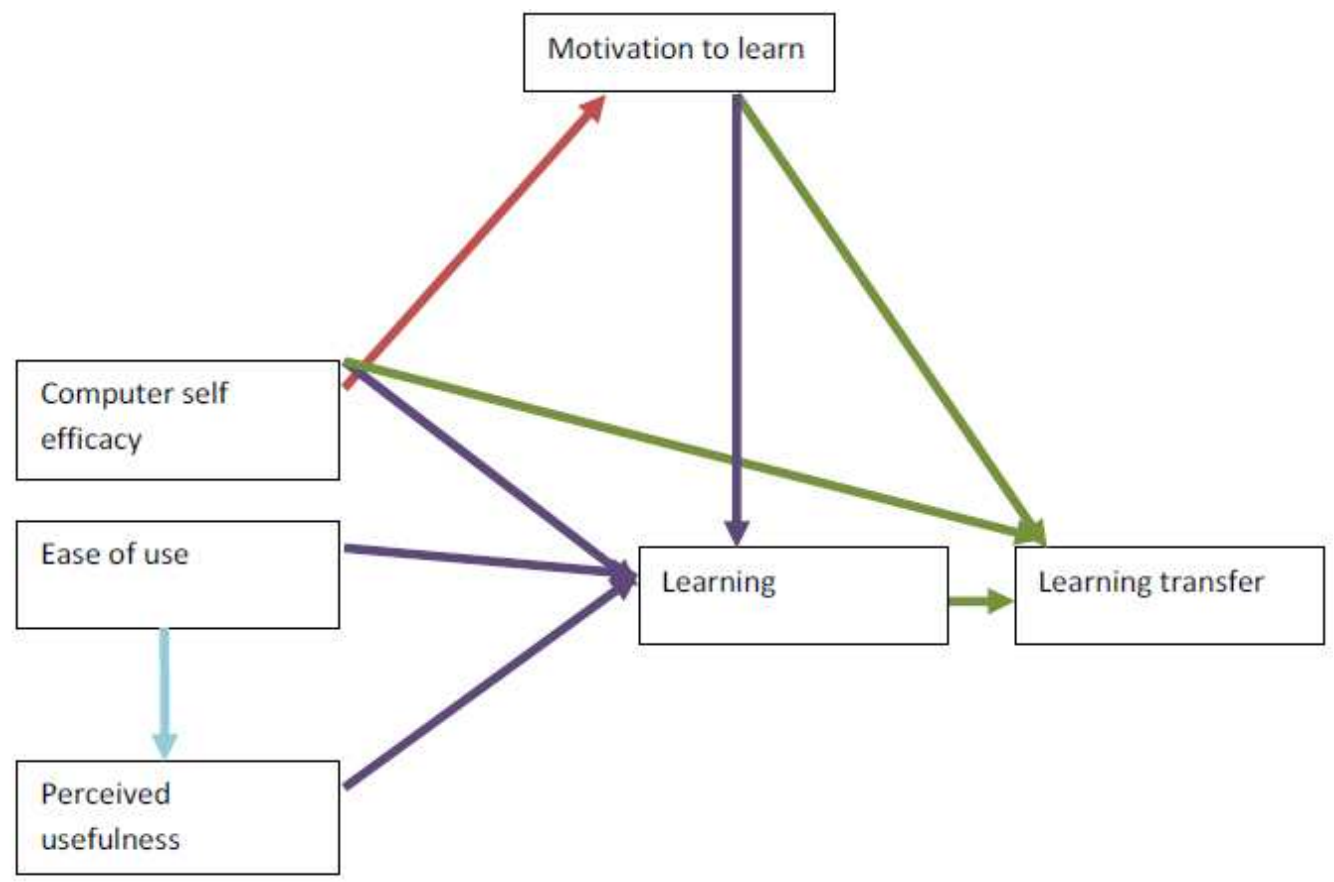

Fig 1. E-learning outcomes model

\section{Individual factors: motivation and self efficacy}

\section{Motivation}

Motivation has been defined as the degree to which trainees are willing to make efforts to enhance his or her performance of learning and work (Mitchell, 1982; Meyer\& Becker, 2004). Moreover, Noe (1986) defined motivation as the specific desire of the employee to learn the program content. The previous research demonstrated that the motivation to learn predicts learning outcomes and is influenced by both individual and situational factors (Noe, 1986; Mathieu \& al, 1992, 1993; Martocchio \& Webster, 1992; Quinones, 1995; Colquitt \& al,
2000).Moreover, several studies associated motivation to learning to the training effectiveness; we can mention the research of Mathieu, Tannenbaum and Salas (1992), in this study emotional responses to the program, moderate the relation between motivation to learn and learning. In fact, the stronger trainees express more positive emotional responses, the stronger the relation between motivation to learn and the learning will be. Colquitt \& al (2000) argued that this construct is correlated to skill acquisition.

Motivation to transfer has been defined as the desire of the employees to use program content to work performance after training 
(Noe, 1986). Therefore, motivation to transfer plays a relevant role on the learning achievement and the change of employees' behavior after training (Noe, 1986; Holton, 1996; Yamnill\& Mcclean, 2001).

\section{Self efficacy}

Self efficacy has been shown to influence the behavior of individuals towards the execution of actions. Moreover, self efficacy is an individual's belief about his or her capacity to mobilize the resources requisite for successful task performances (Bandura, 1986). According to social cognitive theory (Bandura, 1986), self efficacy is postulated to influence performance in interpersonal skills training (Gist, Stevens \& Bavetta, 1991), in military training programs (Eden \& Ravid, 1982; Tannenbaum \& al, 1991), in computer software training (Gist, Schwoerer, \& Rosen, 1989), and home page design training course ( Chau \& Wang, 2000).

Mathieu, Martineau, Jennifer \& Tannenbaum (1993) found that individual antecedents of self efficacy (initial performance, achievement motivation and choice) influence self efficacy development. In this context, the authors found that self efficacy influences trainees' reactions and performance improvement during training. Hill, Smith \& Mann (1987) examined the relationship between self efficacy and the readiness to use computers. Results indicated that efficacy beliefs predict the behavioral intentions related to learning about computers. Moreover, Latham \& Frayne, (1989) found a relationship between self efficacy and performance both during training and nine months after the completion of training. In the study, the researchers showed that training could increase the perceived self efficacy of unionized workers, and that the higher the perceived self efficacy of these unionized workers, the better their subsequent job performance.

Ford, Quinones, Sego and Sorra (1992) examined the effects of individual characteristics on type of tasks performed after four months on the job. The researchers concluded that individuals high in self efficacy were more likely to perform tasks for which they were trained. This study intends to check the relationships between trainees learning motivation and computer self efficacy and the effectiveness of e-learning.

Social cognitive theory considers that computer self efficacy constitutes a significant factors of motivation (Bandura and Wood, 1989). In this case, persons appear to be more motivated when they express a great believe in their capabilities to achieve targeted goals. In this perspective, self efficacy plays an important role in trainees' motivation.

We therefore hypotheses:

H1: Motivation to learn influences positively learning outcomes.

H1-1: Motivation to learn influences online learning.

H1-2: Motivation to learn influences learning transfer.

H2: Computer self efficacy influences elearning outcomes.

H2-1: Computer self efficacy influences online learning.

H2-2: Computer self efficacy influences learning transfer.

H3: Computer self efficacy influences motivation to learn positively.

\section{Perceptual factors: ease of use and perceived utility}

\section{Perceived Ease of use}

The investment in applications of information technology (e.g. e-learning) can derive to productivity gains if they are accepted and used by the end-users (Venkatesh, 1999, 2000). Several theoretical models focus on the importance of trainees' perceptions of ease of use, which is successful in predicting and explaining actual intention and usage behavior across business areas (Davis, 1989; Davis \& al, 1989). In this case, perceived ease of use is defined as "the degree to which an individual 
believes that using a particular system would be free of physical and mental effort." (Davis, 1989, p.320).

In the context of the online training environment, Ngai \& al (2007) argued that technical support presents a meaningful direct effect on the perceived ease of use of learning material. Moreover, Zhang \& Zhou (2003) developed a system "e-learning" based on the multimedia. They found that this system is useful and interactive, facilitating the communication between trainees and virtual trainers. Authors argued that, to improve training effectiveness, online training environment must provide a structural support to multimedia instruction and predict the learning achievement. Piccoli \& al (2001) suggested that virtual training environment must facilitate communications between physically and geographically separated trainees.

They suggested, text, hypertext, graphics, computer animations, dynamic content as a part of ease of interaction design between system and trainees. Similarly, Leidner \& Jarvenpaa (1995) considers debate rooms, virtual rooms and simulations as a part of ease of use interaction between training material and trainees. Zhang \& al (2006) argued that trainee success can be captured when they can use an interactive video system providing an appropriate interaction.

\section{Perceived usefulness}

Perceived usefulness is defined as "the degree to which an individual believes that using a particular system would enhance his or her job performance" (Davis, 1989, p.320). Perceived usefulness is hypothesized to predict learning. For example, Chiu, Hsu, Sun, Liu and Sun (2005) demonstrated that perceived usefulness influence positively e-learning effectiveness by the measure of trainees' satisfaction. In addition, Johnson, Hornik and Salas (2008) established that perceived usefulness influence positively e-learning effectiveness. Specifically, perceived usefulness was related to course instrumentality $(\beta=.303, p<.001)$, course performance $(\beta=.100, p<.05)$, and course satisfaction $(\beta=.222, \mathrm{p}<.001)$.

Based on technology acceptance model, several researchers demonstrated that perceived ease of use played a significant role in predicting perceived usefulness (e.g. Davis, 1993; Saadé and Bahli, 2005). For example, Saadé and Bahli (2005) found a positive and significant relationship between perceived ease of use and perceived usefulness ( $p a t h=0.28, p<0.01$ ).

Consequently, we predict the following hypotheses:

H4: Perceived ease of use influences positively learning

H5: Perceived usefulness influences positively learning.

H6: Perceived ease of use influences positively perceived usefulness.

\section{E-learning outcomes}

Alliger \& al (1997) focus on the importance of training effectiveness. They argued that the training effectiveness model needs to include many more variables than are typically included in a taxonomy advanced by Kirkpatrick. Lim \& al (2007) suggested that trainee reaction and learning are studied as central indicators of training outcomes. However, they considered that these variables are no appropriate indicators of the final outcome of training programs. Therefore, a suitable evaluation of training outcomes is made by measuring the relationships between learning goals achievement and behavior change on the job.

(Kraiger, Ford, \& Salas, 1993).The integration of training program within an organization must improve the performance of this last. Therefore, trainees in charge must perform training program and transfer new knowledge, 
skills and behavior learned during training (Lim \& al, 2007).

Baldwin \& Ford (1988) elaborated an integrated model on the process of learning and transfer (Lim \& al, 2007).They defined learning effectiveness as a trainees' knowledge, skills and behavior learned in a training session and their effective application on their job. Empirical research on learning effectiveness focuses on the predictor of learning and examining their relationships with transfer (e.g., Ford, Smith, Weissbein, Gully, and Salas, 1998; Lim et al., 2007). Learning refers to the learners' skills and knowledge acquired during training experience (Kirkpatrick, 1996). Transfer refers to the learners' change of their behavior on the job because of training experience (Kirkpatrick, 1996).

Alliger \& al (1997) argued that learning has a significant impact on transfer. Moreover, Colquitt \& al (2000) argued that learning outcomes (e.g. knowledge acquisition, reactions) affect directly knowledge transfer into daily routines. Based on previous research, the relationship between learning and learning transfer is hypothesized as associate:

H7: Learning influences learning transfer positively.

\section{Research method}

\section{Measures}

Items (presented in table 1) proposed to assess the constructs were adopted from prior research work. The items were validated in a pilot study close to forty employees. No difficulty of understanding has been found and therefore no modification has been introduced to the constructs items. All items were measured using five -point Likerd-type scale with anchors from "Strongly disagree" to "Strongly agree".

\section{Set up and procedure}

The empirical study of e-learning effectiveness model has been conducted with close to 410 employees of nine Tunisian enterprises. The choice of these enterprises has been guided by two considerations. For this research, we used a semi-structured interview format. The result showed that nine enterprises are the most advanced concerning e-learning among the contacted enterprises. Moreover, they display a significant budget for training in general and for online training in particular.

\section{Participants characteristics}

Participants were 410 employees in which the proportion of males to females is 55.1 percent to 44.9 percent. Participants varied in age between 20 and 29 years. The mean seniority of participants varied between 10 and 20 years with dominance of administrative post (62.9\%). 
Table1: Research constructs based on prior research work

\begin{tabular}{|c|c|c|c|}
\hline Constructs & items & Measure & Authors \\
\hline $\begin{array}{l}\text { Motivation to } \\
\text { learn }\end{array}$ & $\begin{array}{l}\text { M5 } \\
\text { M6 } \\
\text { M7 } \\
\text { M8 }\end{array}$ & $\begin{array}{l}\text { I am motivated to learn the material in this online } \\
\text { training program. } \\
\text { I tried to learn as much as I can from this online } \\
\text { training program. } \\
\text { I go more from this course than most people. } \\
\text { I tried harder when I have not understood some part } \\
\text { of this online training program. } \\
\text { I put more effort into this course than most people. } \\
\text { I could learn the material presented in this } \\
\text { Online training program. } \\
\text { I exerted considerable effort to learn the content of this online } \\
\text { training program. } \\
\text { Increasing skills through online training program has helped me to } \\
\text { perform my job better. }\end{array}$ & $\begin{array}{l}\text { Noe and Schmitt } \\
\text { (1986) } \\
\text { internal } \\
\text { consistency } \\
\text { reliability } \\
\text { ranged from } \\
0.95 \text { to } 0.98 \text { for } \\
\text { these items }\end{array}$ \\
\hline $\begin{array}{l}\text { Computer } \\
\text { self efficacy }\end{array}$ & $\begin{array}{l}\text { CSE1 } \\
\text { CSE2 } \\
\text { CSE3 } \\
\text { CSE4 } \\
\text { CSE5 } \\
\\
\text { CSE6 } \\
\text { CSE7 } \\
\\
\text { CSE8 } \\
\text { CSE9 } \\
\text { CSE10 }\end{array}$ & $\begin{array}{l}\text { I could complete the online learning tasks using the software packages: } \\
\ldots \text {.. if there was no one around to tell me what to do as I go. } \\
\ldots \text { if I had never used a package like it before. } \\
\text {.. if I had only the software manuals for reference. } \\
\text {... if I had seen someone else using it before trying it myself. } \\
\text {... if I could call someone for help if I got stuck. } \\
\text {.. if someone else had helped me get started. } \\
\text {... if I had a lot of time to complete the task for which the software } \\
\text { was provided. } \\
\text {... if I had just the built-in help facility for assistance. } \\
\text {... if someone showed me how to do it first. } \\
\text {... if I had used similar package like this one before to do } \\
\text { the task. }\end{array}$ & $\begin{array}{l}\text { Compeau } \\
\text { and Higgins } \\
(1995) \\
\text { internal } \\
\text { consistency } \\
\text { reliability } \\
0.81\end{array}$ \\
\hline $\begin{array}{l}\text { Perceived } \\
\text { Ease of use }\end{array}$ & $\begin{array}{l}\text { PEU1 } \\
\text { PEU2 } \\
\text { PEU3 } \\
\text { PEU4 } \\
\text { PEU5 }\end{array}$ & $\begin{array}{l}\text { I find e-learning platform easy to use. } \\
\text { I find it easy to get e-learning platform to do I want it to do. } \\
\text { My interaction with e-learning platform was clear } \\
\text { and understandable. } \\
\text { I find e-learning platform flexible to interact with. } \\
\text { It would be easy to become skillful at using e-learning platform. }\end{array}$ & $\begin{array}{l}\text { Davis } \\
\text { ( } 1989 \text { ) } \\
\text { Internal } \\
\text { consistency } \\
\text { reliability } 0.91\end{array}$ \\
\hline $\begin{array}{l}\text { Perceived } \\
\text { usefulness }\end{array}$ & $\begin{array}{l}\text { PU3 } \\
\text { PU4 } \\
\text { PU5 }\end{array}$ & $\begin{array}{l}\text { Using e-learning platform ameliorate the course understandable. } \\
\text { Using e-learning platform enhanced my effectiveness } \\
\text { in the course. } \\
\text { Using e-learning platform enhanced my interaction with } \\
\text { the instructors. } \\
\text { Using e-learning platform makes it easier to learn. } \\
\text { I find the e-learning platform useful in my learning. }\end{array}$ & $\begin{array}{l}\text { Davis } \\
(1989) \\
\text { Internal } \\
\text { consistency } \\
\text { reliability } 0.97\end{array}$ \\
\hline Learning & L1 & $\begin{array}{l}\text { I believe that, this online course was a very valuable } \\
\text { learning experience for me. } \\
\text { I consider this learning experience as time and effort very }\end{array}$ & $\begin{array}{l}\text { Nehari and } \\
\text { Bender } \\
(1987)\end{array}$ \\
\hline
\end{tabular}




\begin{tabular}{|c|c|c|c|}
\hline & $\begin{array}{l}\text { L14 } \\
\text { L15 } \\
\text { L16 } \\
\text { L17 } \\
\text { L18 } \\
\text { L19 } \\
\text { L20 } \\
\text { L21 }\end{array}$ & $\begin{array}{l}\text { well spent. } \\
\text { This was not a meaningful learning experience. } \\
\text { I believe that this online course was a constructive and } \\
\text { definitely helpful learning experience. } \\
\text { I would like to take another course like this one. } \\
\text { I would not recommend this online course to a friend. } \\
\text { Taking the online course made little difference for me. } \\
\text { I believe that the online course helped me to acquire } \\
\text { important basic knowledge. } \\
\text { I believe that I don't gain much knowledge in this online course. } \\
\text { I believe that I' am now better able to conceptualize } \\
\text { problems presented on the job. } \\
\text { The online course helped me to achieve a deeper understanding } \\
\text { of the work tasks. } \\
\text { This online course did not help me gain thorough knowledge } \\
\text { of thework tasks. } \\
\text { This learning experience helped me to become more aware of } \\
\text { my own feelings and reactions. } \\
\text { This online course had no impact on my personal growth. } \\
\text { This experience helped me to realize the importance of my } \\
\text { own feelings. } \\
\text { In some ways I feel good about myself due to this online course. } \\
\text { Some of my values have been clarified due to this } \\
\text { learning experience. } \\
\text { In this online course I had not developed my own learning goals. } \\
\text { learning than I usually do. }\end{array}$ & $\begin{array}{l}\text { Internal consister } \\
\text { reliability } \\
0.95\end{array}$ \\
\hline $\begin{array}{l}\text { Learning } \\
\text { transfer }\end{array}$ & $\begin{array}{l}\text { LT1 } \\
\text { LT2 } \\
\\
\text { LT3 } \\
\text { LT4 }\end{array}$ & $\begin{array}{l}\text { My work allows me time to try the new things I have learned during } \\
\text { online course. } \\
\text { The activities that I have taught during online course helped } \\
\text { me know how to apply my learning on the job. } \\
\text { I feel I am using what I learned from the training in my daily work. } \\
\text { My job performance has improved since completing that } \\
\text { training program. }\end{array}$ & $\begin{array}{l}\text { Holton, } \\
\text { Bates, } \\
\text { and } \\
\text { Ruona (2000) } \\
\text { The internal } \\
\text { Consistency } \\
\text { Reliability } \\
\text { Ranged } \\
\text { from } \\
0.68 \text { to } 0.85\end{array}$ \\
\hline
\end{tabular}




\section{Analysis and findings}

\section{The factorial analysis}

For the assessment of dimensionality, reliability and validity, exploratory analysis and confirmatory analysis was performed on each concept using SPSS 15.0 and AMOS 7.0. Reliability and the internal consistency of items have been assessed through crombach's alpha situated between 0.7 and 0.85 . Table 2 shows the results of the reliability test.

Table 2: Results of reliability test

\begin{tabular}{lcc}
\hline variables & Number of items & Crombah's alpha \\
& & value \\
\hline
\end{tabular}

\section{Training effectiveness}

\section{Learning}

Learning Transfer

\section{Individual variables}

Motivation

Computer self efficacy

\section{Perceptual variables}

Perceived ease of use

Perceived usefulness
0.813

\subsection{5}

0.816

10

0.785

5

0.854
= 197 nearly 200; and Hoelter.01 index = 206 $>$ 200. Therefore, the fitness of the research model is considered satisfactory.

\section{Results of hypothesis verification}

The results of the hypothesized model has been verified and assessed by using AMOS 7.0. Each hypothesis has been verified by measuring values of standard path, being assessed on the basis of statistical significance 
of $t$ value. From this perspective, the factors influencing trainees' learning are motivation $(\mathrm{t}$ value $=2.346 ;$ standard path $=0.136$ ), perceived usefulness $(\mathrm{t}$ value $=6.871$; standard path $=0.726$ ); Perceived ease of use $(\mathrm{t}$ value $=3.145 ;$ standard path $=0.167)$. Factors influencing trainees' transfer include learning $(\mathrm{t}$ value $=4.465$; Standard path $=$ 0.876). Moreover, computer self efficacy influence motivation to learn $(\mathrm{t}$ value $=2.768$; standard path $=0.289$ ). Also, perceived ease of use influences perceived usefulness $(\mathrm{t}$ value $=$ 2.893; standard path $=0.332$ ).

Final research model is shown in figure 2

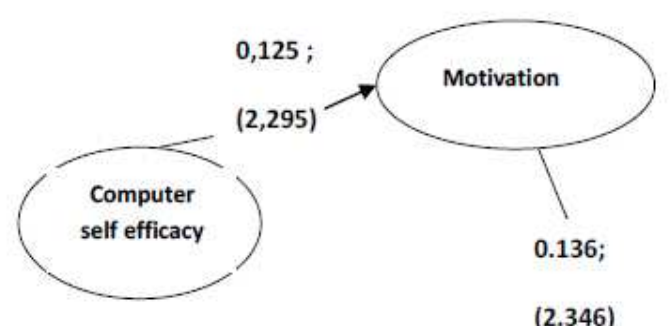

(2.346)

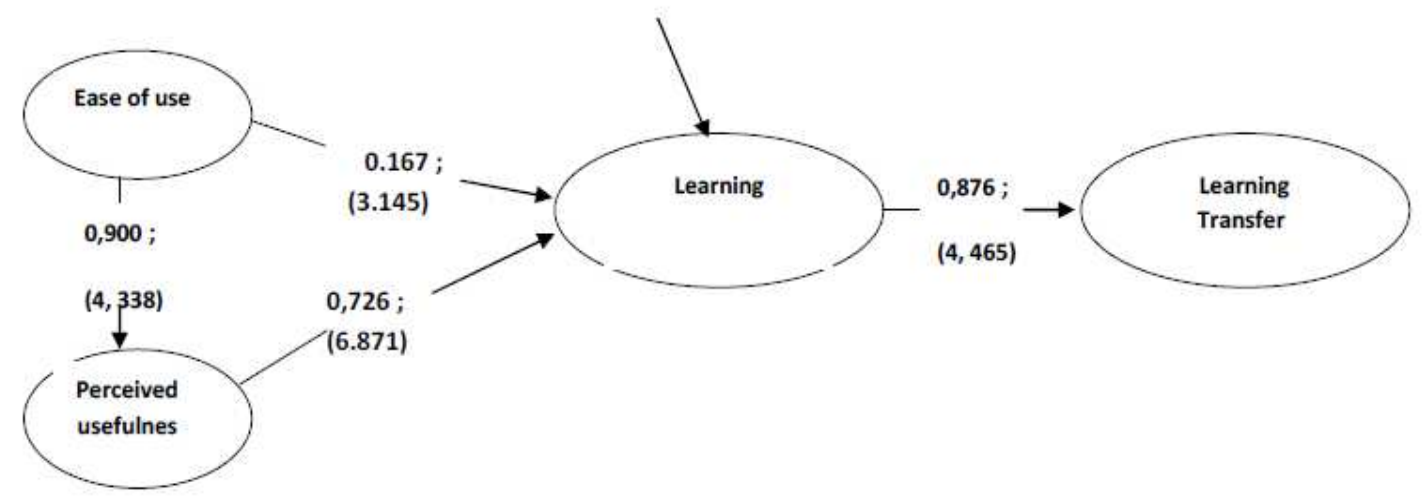

Fig 2. Final model of e-learning effectiveness

\section{Discussion and conclusion}

The purpose of this study was to examine online training program factors to improve elearning effectiveness. Motivation, computer self efficacy, perceived ease of use and perceived usefulness were recognized as possible factors that explain learning outcomes. The research results are as follows.

For Tunisian employees, motivation influences learning. Nevertheless, trainees' learning motivation is a relatively not important variable in learning performance (learning motivation - learning: standard path $=0.136$ ). This result means that employees can be motivated in being registered on the online course by curiosity. Moreover, this result means that trainees' learning motivation can decrease with the advance of training sessions. However, the research result does not suggest any positive relationship between the motivation and the learning transfer. That is trainees' learning motivation has a relatively weak and negative effect in transfer (learning motivation - transfer performance: standard path $=-0.075$ ). Thus, the use of newly knowledge at work is not explained by the 
employees' motivation but rather by the need to apply for new knowledge, skills and behaviors for the performance of the required tasks. These results contradict those found by Lim \& al (2007). The authors showed the important effect of trainees' learning motivation on learning (Standard path = 0.427) and on transfer (Standard path = 0.509). Moreover, several other researchers showed that motivation is an important predictor of training effectiveness (Noe, 1986; Mathieu \& al, 1992, 1993; Colquitt \& al, 2000). In order to emphasize the positive effect of the trainees' learning motivation on e-learning effectiveness, it would be interesting for the human resources responsible to predict several modes of motivation such as: rewards, evolution in the rank of a certain qualification level.

In addition, the effect of the self efficacy on elearning effectiveness was not supported. This result means that trainees who believe more in their abilities and aptitudes to use the computer tools to achieve the desired purpose will not be inevitably most likely to perform training tasks to become more operational for the use of new knowledge and skills in the daily routines of job. By contrast, Lim \& al (2007) showed that self efficacy affects partially e-training effectiveness. According to them, self efficacy seems to influence positively online learning, but trainees' computer self efficacy has no effect on transfer. A previous research demonstrated the significant relationship between trainees' computer self efficacy and learning (e.g. Compeau \& Higgins, 1995). Likewise, the importance of self efficacy for the transfer was shown by many researchers (e.g. Latham \& Frayne, 1989; Martocchio, 1994). Consequently, we can advance that the control of the computer tools does not constitute a handicap for the Tunisian employees since their daily use of it for the performance of their routine tasks. This research demonstrated the important effect of computer self efficacy on motivation to learn. These results are close to social cognitive theory assignment.

The perceived ease of use affects positively learning. Consequently the higher online platform is clear, comprehensible and convivial, fewer efforts are required for trainees and better it will tend to achieve learning. This result is in accordance with several researchers such as (Piccoli \& al, 2001; Zhang \& Zhou, 2003; Zhang \& al, 2006). The research revealed that perceived ease of use influences positively perceived usefulness. This result reinforces the previous research results (e.g. Davis, 1993).

Finally, the influence of learning on the transfer performance is significant (Standard path $=0.876$ ). This result is in accordance with several researchers such as Baldwin \& Ford (1988), Holton (1996), Alliger \& al (1997), Colquitt \& al (2000), Alvarez \& al (2004), Lim $\&$ al (2007). These results seem to be crucial for e-learning effectiveness since the relationship between the two dependent variables was checked. Findings of this study could be helpful for managers to better understand individual and perceptual characteristics needed to improve e-learning systems.

\section{Limitations and Future research}

In spite of the lightings brought by the results of this research, a number of limitations must be announced. First, the choice of e-leaning antecedents remains restricted by considering the whole of the possible factors. In this case, considering social presence, interaction, pedagogical approaches, and feedback in the model are important. Second, this research reflects a first test of a theoretical model and should be subjected to additional investigations with different participants, and contexts. Third, the study participants were employees, so it' is important to make comparison between employees and undergraduate students. Fourth, due to the research questions, the study doesn't fully capture the measure of employees' behavior when considering demographic characteristics influences (e.g. gender...). For an overcoming of this weakness, a measure of the development of trainees' behavior and demographics characteristics and its ongoing reciprocal relationship with other variables in the model is recommended. 
Fifth, regarding the transverse character of the study, the change of the employees' behaviors towards the learning and transfer process through time could not be measured. A longitudinal study could, for this purpose, better delimit the determinants of e-learning effectiveness and their stability through time.

\section{References}

Alvarez, K., Salas, E. and Garofan, C M. (2004), 'An integrated model of training evaluation and effectiveness,' Human Resource Development Review, 3 (4), 385416.

Alliger, G M., Tannenbaum, S I., Bennett, W. and Traver, H. (1997), 'A meta-analysis of the relations among training criteria, ' Personnel psychology, 50 (2), 341- 358.

Bandura, A. (1986) Social foundation of thought and actions: A social cognitive view, Prentice Hall, Englewood Cliffs, New Jersey.

Baldwin, TT. and Ford, J K. (1988), 'Transfer of training: a review and directions for future research,'Personnel psychology, Vol. 41, №1, 63-105.

Bandura, A. and Wood, R. (1989), 'Social cognitive Theory of organizational management,' Academy of Management Review, Vol. 14, ํ3, pp. 361 -384.

Compeau, D. and Higgins, C A. (1995), 'Computer self- efficacy: Development of a measure and initial test,' MIS Quarterly, 19 (2), 189- 211.

Colquitt, J. A. and Lepine, J A. (2000), 'Toward an Integrative theory of training motivation: A Meta - analytic path analysis of 20 years of research,' Journal of Applied Psychology, 85 (5), 678- 707.

Chiu, M., Hsu, M., Sun, S., Liu, C. and Sun, P. (2005), 'Usability, quality, value and elearning continuance decisions,' Computers and Education, vol.45, pp.399-416.
Chau, H W. and Wang, T B. (2000), "The influence of learning style and training method on self - efficacy and learning performance in WWW homepage design training,' International Journal of Information Management, 20, 455-472.

Davis, F D. (1989), 'Perceived usefulness, perceived ease of use, and user acceptance of information technology,' MIS Quarterly, 319- 340 .

Davis, F D., Bagozzi, R P. and Warshau, P R. (1989) 'User acceptance of computer technology: a comparison of two theoretical models,' Management Science, 35(8), pp. 982-1003.

Davis, F. (1993), 'User acceptance of information technology: system characteristics, user perceptions and behavioral impacts,' Inter.J.Man-Machine Studies, Vol.38, pp.475-487.

Eden, D. and Ravid, G. (1982), 'Pygmalion versus self- expectancy: effects of instructor and self expectancy on trainee performance,' Organizational Behavior And Human Performance, 30, 351 - 364.

Gist, M E., Schwoerer, C. and Rosen, B. (1989), 'Effects of alternative training methods on self- efficacy and performance in computer software training,' Journal of applied psychology, 74 (6), 884- 891.

Gist, M E., Stevens, C K., Bavetta, A G. (1991), 'Effects of self-efficacy and posttraining intervention on the acquisition and maintenance of complex interpersonal skills,' Personnel psychology 44 (4), 837861.

Ford, J K., Quinones, M A., Sego, D J. and Sorra, J S. (1992), 'Factors affecting the opportunity to perform trained tasks on the job,' Personnel Psychology, 45 (3), 511527.

Ford, J K., Smith, E M., Weissbein, D A., Gully, S M. and Salas, E. (1998), 'Relationships of goal orientation, Metacognitive activity, and practice strategies with learning outcomes and transfer,' Journal of Applied Psychology, 83 (2), $218-233$. 
Hill, T., Smith, N D. and Mann, M F. (1987), 'Role of efficacy expectations in predicting the decision to use advanced technologies: the case of computers,' Journal of Applied Psychology, 72 (2), 307- 313.

Holton, E F III. (1996), 'The flawed fourlevel evaluation model,' Human Resource Development Quarterly, 7 (1), 5- 21.

Holton, E F III., Bates, R A. and Ruena, W E A. (2000), 'Development of a generalized learning transfer system inventory,' Human Resource Development Quarterly, 11 (4), 333- 360.

Kraiger, K., Ford, J K. and Salas, E. (1993), 'Application of cognitive, skill- based, and affective theories of learning outcomes to new methods of training evaluation,' Journal of applied psychology 78(2), 311328.

Kirkpatrick, D. (1996), 'Great Ideas Revised,' Training\& development, 169, 5559.

Latham, G P. and Frayne, C A. (1989), 'Selfmanagement training for increasing job attendance: a follow-up and a replication,' Journal of Applied Psychology, 74 (3), 411416.

Leidner, D E. and Jarvenpaa, S L. (1995), ' The use of information technology to enhance management school education: a theoretical view,' MIS Quarterly, 19 (3), 265 $-291$.

Lim, H., Lee, S G. and Nam, K. (2007), 'Validating E-learning factors affecting training effectiveness,' International Journal of Information Management, 27, 2235.

Martocchio, J J. (1994), 'Effects of conceptions of ability on anxiety, selfefficacy, and learning in training,' Journal of Applied Psychology, 79 (6), 819 - 825.

Martocchio, J J. and Webster, J. (1992), 'Effects of feedback and cognitive playfulness on performance in microcomputer software training,' Personnel Psychology, 45 (3), 553- 578.
Mathieu, J E., Tannenbaum, S I. and Salas, E. (1992), 'Influences of individual and situational characteristics on measures of training effectiveness,' Academy of management journal, 35 (4), 828 - 847.

Mathieu, J E., Martineau, J W. and Tannenbaum, S I. (1993), 'Individual and situational influences on the development of self efficacy: Implications for training effectiveness,' Personnel Psychology, 46 (1), 125- 147.

Meyer, JP., Becker, T E. (2004), 'Employee Commitment and motivation: a conceptual analysis and integrative model,' Journal of Applied Psychology, 89 (6), 991-1007.

Mitchell, T R. (1982), 'New directions for theory, research, and practice,' Academy of management journal, 2 (1), 80 - 88.

Nehari, M. and Bender, H. (1978), 'Meaningfulness of a learning experience: a measure for educational outcomes in higher education,' Higher Education, 7 (1), 1- 11.

Noe, R A. (1986), 'Trainees' attributes and attitudes: neglected influences on training effectiveness,' Academy of management review, 11(4), 736- 749 .

Noe, R A. And Schmitt, N. (1986), "The influence of trainee attitudes on training effectiveness: that of a model," Personnel Psychology, 39, 497 - 523.

Ngai, EWT., Poon, J K L. and Chan,Y H C. (2007), 'Empirical examination of adoption of WebCT using TAM," Computers and Education, 48, 250- 267.

Saadé,R . and Bahli, B. ( 2005), ' The impact of cognitive absorption on perceived usefulness and perceived ease of use in on -line learning: an extension of the technology acceptance model,' Information and management, 42, 317-327.

Johnson, R D., Hornik, S. and Salas, E. (2008), 'An empirical examination of factors contributing to the creation of successful e-learning environments,' 
International Journal of Human Computer Studies, 66, 356 - 369.

Piccoli, G., Ahmad, R. and Ives, B. (2001), 'Web- based virtual learning environments: a research framework and a preliminary assessment of effectiveness in basic IT skills training,' MIS Quarterly, 25 (4), 401426.

Quinones, M A. (1995), 'Pretraining context effects: training assignment as feedback,' Journal of Applied Psychology, 80 (2), 226238.

Tannenbaum, S I., Mathieu, J E., Salas, E. and Cannon - Bowers, J A. (1991), 'Meeting trainees' expectations: the influence of training fulfilment on the development of commitment, self - efficacy, and Motivation,' Journal of Applied Psychology, 76 (6), $759-769$.

Venkatesh, V. (1999), 'Creation of favourable user perceptions: exploring the role of intrinsic motivation,' MIS Quarterly, 23 (2), $239-260$.

Venkatesh, V. (2000), 'Determinants of perceived ease of use: integrating control, intrinsic motivation, and emotion into the technology acceptance model', Information systems research, 11(4), 342- 365.

Yamnill, S. and Mclean, G N. (2001), 'Theories supporting transfer of training,' Human Resource Development Quarterly, 12 (2), $195-208$

Zhang, D. and Zhou, L., (2003), "Enhancing E-learning with Interactive Multimedia", Information Resources Management Journal, $16(4), 1-14$.

Zhang, D., Zhou, L., Briggs, R O. and Nunamaker, J.F. (2006), 'Inqstructional video in e-learning: Assessing the impact of interactive video on learning effectiveness,' Information and Management, 43, 15- 27. 